Journal of Social and Development Sciences

Vol. 4, No. 10, pp. 446-448, Oct 2013 (ISSN 2221-1152)

Book Review

\title{
The Ascent of Money: A Financial History of the World
}

\author{
Author: Niall Ferguson \\ Reviewed by: Shiva Kumar Srinivasan \\ Behavioral Sciences, IIPM Chennai, India \\ sksrinivasan2008@hotmail.com
}

\section{Introduction}

John Kenneth Galbraith, the Harvard economist, was fond of asking two important questions about money: 'Whence it comes? Where it goes?' It is precisely these questions that Niall Ferguson, who is also based at Harvard, wishes to address here albeit with an important difference. While Galbraith wrote as an economist; Ferguson writes as an historian of finance. They however share an ethical passion in common: the need to educate the layperson by contributing to the challenge of financial literacy. And, again, they share a common preoccupation with the problem of economic downturns and financial crises in the Anglo-American world; which, more often than not, is not just a theoretical question for academics but takes on the form of a difficult lived experience for large sections of the population when the viability of firms, investments, or livelihoods might be at stake. What Galbraith and Ferguson are determined to get across in their work is the simple, but oft-forgotten, lesson that financial crises are endemic to capitalism as such and therefore cannot be solved merely as a set of contingent, technical, problems of the macro-economy. Instead, they must be understood in terms of how crises repeat themselves within the history of economics and finance; it is therefore important to know where financial institutions are coming from, why they were set up, the constraints under which they function, the regulatory provisions that determine their boundaries, and so on, in order to understand what they are up to at any point in time.

\section{Financial Literacy}

Galbraith and Ferguson are also committed to the idea that a serious theoretical inquiry into these questions is not merely of academic interest but must be communicated to as large an audience as possible, so that the learning from such an exercise not only passes on to how the population at large thinks about taking financial decisions in their everyday life; but, are also able to appreciate the constraints and demands on policy makers when they have to take decisions that affect the macro-economy. The need to understand and explain how the macro-economy works is also linked to the idea that financial literacy is a prerequisite to exercise the freedoms and the rights that are enshrined in the Anglo-American notion of political subjectivity. This is a passion that is also to be found, for instance, in how financial institutions define the need, on their part, to communicate the significance of their decisions to their constituents, especially in situations such as the economic meltdown of 2008. Understanding the role played by Galbraith as an important 'predecessor', as Harold Bloom might put it, then is an interesting way of both appreciating and situating Ferguson's work. This book is also accompanied by a television series given, not surprisingly, the seriousness that Ferguson attaches to the idea of communicating with as large an audience as possible.

\section{What is Money?}

What then is money? What is the role that it has played in the history of finance? What is it that Ferguson wants us to know in addition to the usual descriptions of money in textbooks of macroeconomics? What will the differences be in terms of how the reader will think about problems of decision-making after reading this book in everyday life? Only the first of these questions, I am afraid, has a direct answer; the rest require a willingness to think about the relationship between the structural and historical dimension of financial scholarship. Ferguson starts with the usual definition of money as a 'unit of account', 'medium of exchange', and 'store of value' before listing its varied properties. While this is only to be expected, what Ferguson is able to do as a master storyteller is to weave the historical instances which illustrate or problematize the functions and properties of money within a narrative framework that works on the analogy of the evolutionary 
dynamics of financial institutions. The evolutionary model that he invokes is actually that of the Harvard biologist Stephen Jay Gould who introduced the idea of a 'punctuated equilibrium' to explain the temporal order within which species evolve. This, to put it simply, is both linear and non-linear at the same time; the development and maturation of financial institutions then works in 'fits-and-starts' and is not necessarily a smooth progression towards a higher order.

\section{The Evolutionary Analogue}

Ferguson was also influenced by Jacob Bronowski's book-cum-television series on evolution which was titled the Ascent of Man. So unlike the routine textbook invocation of money, which is an attempt to set out a definition and enumerate its possible applications in technical contexts, Ferguson makes available here an evolutionary account of money by situating it within a set of historical instances that throw light on both the structural and historical dimensions of its evolution. I repeat this point in a slightly modified form because it is an essential clue to Ferguson's style of both thinking and writing about problems in the history of finance. So, for instance, Ferguson punctuates his own narrative from time to time to ask not merely where we are in terms of financial history from a chronological point of view, but in terms of evolutionary dynamics. Should contemporary financial circumstances, he wonders, be explained as akin to 'the end-Permian extinction that killed off 90 percent of the Earth's species, or the Cretaceous-Tertiary catastrophe that wiped out the dinosaurs?' This then is precisely the cognitive advantage in situating technical questions as a series of analogues to evolutionary biology rather than set out the basic notions of money as a prelude to a mere technical discussion. So a cognitive tool, for Ferguson, given that he is a narrative historian, must make it possible to solve problems analogically when a technical resolution is not possible within mainline financial theory. By importing and exporting analogues, then, a quandary in financial theory can be understood via evolutionary biology and vice versa. While Ferguson does not discussion the implications of exporting analogues from finance to evolutionary biology, it is something that an academic reader well-versed in these areas or a philosopher of science may want to attempt to see what insights, if any, can be generated through this process. This, needless to say, is an astonishingly different way of thinking about the unresolved issue of contemporary finance rather than leave them as problems dictated by a pure set of contingencies. Ferguson then goes on to list six important problems of contemporary finance comprising areas such as the problem of over-leverage, securitization of mortgages, the definition of inflation in central banking, the role of the insurance sector in spreading risk through derivatives, attempts to increase home-ownership in the AngloAmerican world through the mortgage market, and the role of Chinese savings in financing the current account deficit in the U.S. economy.

Joseph Schumpeter on 'Creative Destruction': The larger question that has to be thought-through in the context of this evolutionary analogy is its epistemological validity. To what extent, to put it simply, can a cross-domain mapping be attempted? Ferguson again argues that there are at least six important features in common between financial and biological systems. They include the gene-meme parallel, spontaneous mutation as a model for innovation, competition for resources, natural selection (i.e., 'the survival of the fittest'), speciation which translates into creating new types of institutions, and extinction. In Ferguson's formulation, 'financial history is essentially the result of institutional mutation and natural selection'. It is however important to remember that evolutionary processes are not necessarily 'progressive' in the socioeconomic or even political sense - so undesirable types of life forms may continue to exist even as new forms are born. The existence of complexity per se is not a guarantee against the possibility of extinction. The analogue to evolutionary biology is not specific to Ferguson's work since, as he points out, it is related to the notion of 'creative destruction', which appeared initially in the work of Joseph Schumpeter as the 'essential fact about capitalism'. In terms of recent financial history, Ferguson argues that the proliferation of firms and the myriad set of innovations in the financial sector are not unlike 'a twenty year Cambrian explosion, with existing species flourishing and new species increasing in number. As in the natural world, the existence of giants has not precluded the evolution and continued existence of smaller species'.

Joseph Schumpeter on Adaptive Capacity: Ferguson also compares the role played by 'geopolitical shocks' and 'financial crises' in serving as forms of disruption as akin to asteroid hits in the 'Cretaceous period', which 'eliminated 85 percent of species'. The periods referred to as The Great Depression and The Great Inflation in economic and financial history are important cases in point. Needless to say, the inability to solve a crisis can 
lead to forms of extinctions when firms just disappear much to the shock of the investors and the financial community. The extinction is essentially related to the lack of adaptability between the species and the environment. This again was anticipated by Joseph Schumpeter who argued that 'this economic system cannot do without the ultima ratio of the complete destruction of those existences which are hopelessly unadapted'. Neither the state nor the firms can do the job on their own; it is therefore important to remember that the history of finance reveals a state of interdependency between the government and the economy. So unlike species which have to address the question of adaptation in terms of how they relate only to the natural environment, here, given the presence of regulation, what is at stake is more in the form of 'intelligent design'. As Ferguson points out, 'sudden changes to the regulatory environment are rather different from sudden changes in the macroeconomic environment, which are analogous to environmental changes in the natural world'. Wherein lay the difference? According to Ferguson, 'the difference is once again that there is an element of endogeneity in regulatory changes, since those responsible are often poachers turned gamekeepers'. New regulatory requirements make demands on the 'adaptive capacity' of firms which may not be up to the task, and therefore, it is difficult to predict the consequences of regulation. Furthermore, the special treatment that is meted out to the finance sector has come under criticism despite its perceived systemic importance in the context of the 'moral hazard' problem. Ferguson argues that a better way of thinking about this problem might be to think of the failure of big firms in the context of creative destruction. It was only by letting Lehman Brothers fail, he argues, that it became possible for the Bush administration to make an effective case for the $\$ 700$ billion that went into the Troubled Asset Relief Program (TARP) since it would not have been viable to save both Lehman and Merrill Lynch.

\section{Conclusion}

While there are a number of books that cover the same ground as Ferguson in terms of chronicling the main set of events under the aegis of financial history, what is at stake here is not just the rendition of 'events', but the attempt to forge new forms of cognition, engage with the question of financial literacy, and work with a clear notion of pedagogical intent in terms of getting readers to think about the demands of decision making in the context of finance that makes Ferguson's book a valuable contribution. That is why I have tried to delineate what is cognitively at stake in Ferguson's account of recent financial events which have systemic implications without merely reiterating a list of important events. The ethical quandaries posed for policy makers by the problem of 'moral hazard' as opposed to that of 'creative destruction' must both be thoughtthrough in this context since they both makes enormous demands on policy makers for clarity and rationality in the process of decision making. While Ferguson has taken a stand on some of these issues, he is not trying to impose solutions on policymakers. Instead he sets out the range of cognitive options available in such morally trying situations rather than just list a set of policy options. It is this cognitive take on thinking through the rational and ethical demands of policy making, where the interests of particular firms have to be weighed against the regulatory demands of the system as a whole, that Ferguson uses as a differentiating strategy in his capacity as a thinker and writer on financial history. 